\title{
THE CHEMICAL INDUCER, BTH (BENZOTHIADIAZOLE) AND ROOT COLONIZATION BY MYCORRHIZAL FUNGI (GLOMUS SPP.) TRIGGER RESISTANCE AGAINST WHITE ROT (SCLEROTINIA SCLEROTIORUM) IN SUNFLOWER
}

\author{
Rita BÁn, ${ }^{1}$ * Gellért Baglyas, ${ }^{1}$ Ferenc Virányi, ${ }^{1}$ Balázs Barna, ${ }^{2}$ \\ Katalin Posta, ${ }^{3}$ JÓzSeF KISs ${ }^{1}$ and Katalin KÖRÖSI ${ }^{1}$ \\ 'Plant Protection Institute, Szent István University, Páter K. u. 1, H-2100 Gödöllö, Hungary \\ 2Plant Protection Institute, Research Centre for Agriculture, Hungarian Academy of Sciences, \\ Herman O. u. 15, H-1022 Budapest, Hungary \\ 3Institute of Genetics and Biotechnology, Szent István University, \\ Páter K. u. 1, H-2100 Gödöllö, Hungary
}

(Received: July 7, 2016; accepted: October 24, 2016)

\begin{abstract}
White rot caused by Sclerotinia sclerotiorum (SS) is one of the most devastating plant diseases of sunflower. Controlling this pathogen by available tools hardly result in acceptable control. The aim of this study was to elucidate the effects of plant resistance inducers, BTH (benzothiadiazole in Bion $50 \mathrm{WG}$ ) and arbuscular mycorrhizal fungi (AMF) on disease development of white rot in three sunflower genotypes. Defence responses were characterized by measuring the disease severity and identifying cellular/ histological reactions (e.g. autofluorescence) of host plants upon infection. Depending on the host genotype, a single application of inducers reduced disease symptoms. Histological examination of host responses revealed that $\mathrm{BTH}$ and/or AMF pre-treatments significantly impeded the development of pathogenic hyphae in Iregi szürke csíkos and P63LE13 sunflower plants and it was associated with intensive autofluorescence of cells. Both localized and systemic induction of resistance was observed. Importantly, the frequency of mycorrhization of hybrid P63LE13 and PR64H41 was significantly increased upon BTH treatment, so it had a positive effect on the formation of plant-mycorrhiza interactions in sunflower. To our knowledge, this is the first report on the additive effect of BTH on mycorrhization and the positive effect of these inducers against SS in sunflower.
\end{abstract}

Keywords: Arbuscular mycorrhizal fungi - Bion $50 \mathrm{WG}$ - induced resistance - SAR - Sclerotinia rot

\section{INTRODUCTION}

Sclerotinia sclerotiorum (Lib.) de Bary (SS) is one of the most devastating plant pathogens causing disease in a wide range of plants. The polyphag character of SS and the lack of a high level of host resistance results in the general difficulty of controlling this pathogen by available tools [23]. Induced resistance (IR) against pathogens represents one of the most relevant alternative approaches in disease control [28]. Treatment of plants with a variety of biotic and abiotic agents can induce resistance locally or systemically to subsequent pathogenic attack. Such an increased

*Corresponding author; e-mail address: ban.rita@mkk.szie.hu 
resistance rarely results in complete disease control but can be long-lasting and effective against a broad-spectrum of pathogens [22].

The chemical inducer, BTH (benzo $(1,2,3)$ thiadiazole-7-carbothioic acid S-methyl ester, benzothiadiazole) is one of the best studied resistance inducers (activating systemic acquired resistance, SAR) that has been successfully used in practice as the commercial product Bion $50 \mathrm{WG}$ [17]. BTH has been shown to activate resistance in many crops against a broad spectrum of diseases such as powdery mildew in barley and wheat [11], pea rust [4] and Sclerotinia diseases in melon [5] and soybean [8]. Similar activity was found to occur in sunflower against downy mildew [3, 14, 24] and rust disease [20].

Moreover, arbuscular mycorrhizal fungi (AMF) also can be used for enhancing resistance (induced systemic resistance) against plant diseases and are considered to be one of the most efficient biocontrol agents. They have been shown to reduce damage caused by soil-borne pathogens [9] and are effective against some biotrophs [7, 19]. Using two Glomus species in common bean resulted in good effectivity against SS [1]. We also found that the mycorrhiza like endophytic root-colonising fungus Piriformospora indica protects barley roots from damage caused by another necrotrophic pathogen, Fusarium culmorum [12].

In spite of their positive effects as single agents on the constraint of diseases, there is little data about the combined application of BTH and AMF against pathogens [18, 25]. The aim of this study, therefore, was to elucidate the effects of BTH and AMF in combination on disease development of Sclerotinia sclerotiorum in three sunflower genotypes with different resistance levels to the pathogen. Although preliminary results with plant activators showed positive activity against various diseases, the mechanism of SAR is still poorly understood. Another goal of this project, therefore, includes the characterization of defence responses taking place in induced sunflowers. Defence responses were characterized by measuring disease severity and identifying cellular/histological reactions of host plants upon infection. Examining the relationship (synergistic or antagonistic effect) between the chemical inducer BTH and the arbuscular mycorrhizal fungi as biocontrol agents was also a key domain in this study.

\section{MATERIALS AND METHODS}

\section{Plant material}

Sunflower genotypes with different levels of susceptibility/tolerance to SS were used: cv. Iregi szürke csíkos (ISZ, moderately susceptible to stalk and head rot), PR64H41 (PR64) and P63LE13 (P63) hybrids, which are tolerant to head rot and to stalk rot, respectively (Piukovics L., personal communication). 


\section{Pathogen inoculum and disease assessment}

S. sclerotiorum (strain Sz24) from the collection of Szent István University, SzIU) was preserved on potato dextrose agar at $4{ }^{\circ} \mathrm{C}$. Pathogenicity of the strain was checked by culturing on tomato agar and inoculating one of its natural hosts (e.g. carrot) prior to experimental use. Inoculation of 21-day-old sunflower plants was performed by placing mycelial discs of 4-day-old fungal cultures (grown on tomatoagar media and cut with core-borer $(d=8 \mathrm{~mm})$ ) on the basal part of the plants. Disease development (as disease severity) was rated periodically by using the following scale: 0 , no symptoms; 1 , brown rot on the stem base, plant is still standing; 2 , plant is wilted, laying on the ground; 3 , plant is dead. Disease severity was determined as the following:

$$
D S=\frac{\sum(f * v)}{N * X} \times 100
$$

where $D S$ - disease severity; $f$-infection class frequencies; $v$ - number of plants of each class; $N$ - total of observed plants; $X$ - highest value of the evaluation scale.

\section{Treatment by inducers and set-up of experiments}

Experiments were conducted at the Plant Protection Institute of SzIU (Gödöllö, Hungary). Pregerminated seeds were soaked in an aqueous solution of BTH (Bion 50 WG, Syngenta Hungary, $320 \mathrm{ppm}$ ) for $2 \mathrm{~h}$. Treated sunflower seeds were sown in trays ( 75 seeds per tray) containing coarse-grained sand ( $d=0$ to $4 \mathrm{~mm}$ ) in a greenhouse. Before sowing a commercial mycorrhizal product Symbivit ${ }^{\circledR}$ [mixture of G. intraradices, G. mosseae, G. etunicatum, G. claroideum, G. microaggregatum, G. geosporum produced by Symbiom Ltd. (Czech Republic, www.symbiom.cz)] was applied as a biological inductor at a dosage of $25 \mathrm{~g}$ per L substrate. Plants were maintained for four weeks in the greenhouse.

Twenty-one-day-old plants were inoculated with SS by placing mycelial discs of the strain $\operatorname{Sz} 24(d=8 \mathrm{~mm})$ on the stem base. Disease severity was assessed three times at 2, 4 and 7 days after inoculation (dpi), using a 0-3 scale, described above. The experiment was set-up in a randomized blocked design with the following variables: (0) non-treated, non-inoculated by SS, (B) BTH-treated, non-inoculated by SS, (M) mycorrhiza-mediated, non-inoculated by SS, $(\mathrm{B}+\mathrm{M}) \mathrm{BTH}$-treated and mycorrhiza-mediated, non-inoculated by SS, (I) inoculated by SS, non-treated, (B+I) BTHtreated and inoculated by $\mathrm{SS},(\mathrm{M}+\mathrm{I})$ mycorrhiza-mediated and inoculated by $\mathrm{SS}$, $(\mathrm{B}+\mathrm{M}+\mathrm{I}) \mathrm{BTH}-$ treated and mycorrhiza-mediated, inoculated by SS. 


\section{Examining plant defence reactions by microscopy}

Histological examination of BTH treated and/or mycorrhiza-mediated, and nontreated host-pathogen combinations was undertaken by fluorescence microscopy (Olympus, Japan; filter block BX 50, excitation $485 \mathrm{~nm}$, transmission $>515 \mathrm{~nm}$ ). Hypocotil samples ( 5 samples for each treatment) were taken at 2 and 4 dpi. Plant tissues were fixed in FAA solution (formaldehyde:glacial acetic acid:ethyl alcohol: distilled $\left.\mathrm{H}_{2} \mathrm{O}=2: 1: 10: 7\right)$. A series of cross-sections of sunflower hypocotils were then examined under the microscope at $\times 400$ magnification to detect fungal elements (hyphae) and host cell responses (cell death, autofluorescence of cells). Sections were examined unstained.

\section{Evaluation of the degree of colonization by AMF}

Five plants per treatments (only non-inoculated by SS) were used to detect AMF colonization of 21-day-old sunflowers. The roots were cleared in $10 \% \mathrm{KOH}$ for 15 $\min$ at $90{ }^{\circ} \mathrm{C}$, acidified with $5 \%$ acetic acid for $2 \mathrm{~min}$, and stained with $5 \%$ aniline blue in acetic acid for $1 \mathrm{~min}$. For each root system, 30 fragments of $1 \mathrm{~cm}$-length were randomly selected. The AMF root colonization was assessed using a light microscope $(\times 400)$ [26]. Parameters of mycorrhization were calculated with the MYCOCALC software package [16]. The following parameters were counted: (i) F (\%), frequency of mycorrhization (the ratio of infected and non-infected root fragments), (ii) $\mathrm{M}(\%)$, intensity of mycorrhization (the amount of root cortex colonized by mycorrhiza) and (iii) A (\%), arbuscules abundance (the presence of arbuscules in the root system).

\section{Statistical analysis}

Experiments were carried out twice, with each experiment containing three replicates. After standardization (substract mean and divide by standard deviation) data were subjected to analyses of variance. Fisher's test at $p<0.05$ was used for mean separation. Statistical analyses were performed using the software package Minitab 16.1.1. (Minitab Ltd., UK).

\section{RESULTS}

\section{Effect of inducers on disease severity of $\mathrm{S}$. sclerotiorum}

The influence of BTH treatment and mycorrhizal colonization on the development of Sclerotinia rot in three sunflower genotypes at 4 dpi is presented in Figure 1. There were no significant differences in the resistance/tolerance of the 3 sunflower genotypes using our aggressive isolate and inoculation method because control inoculated 


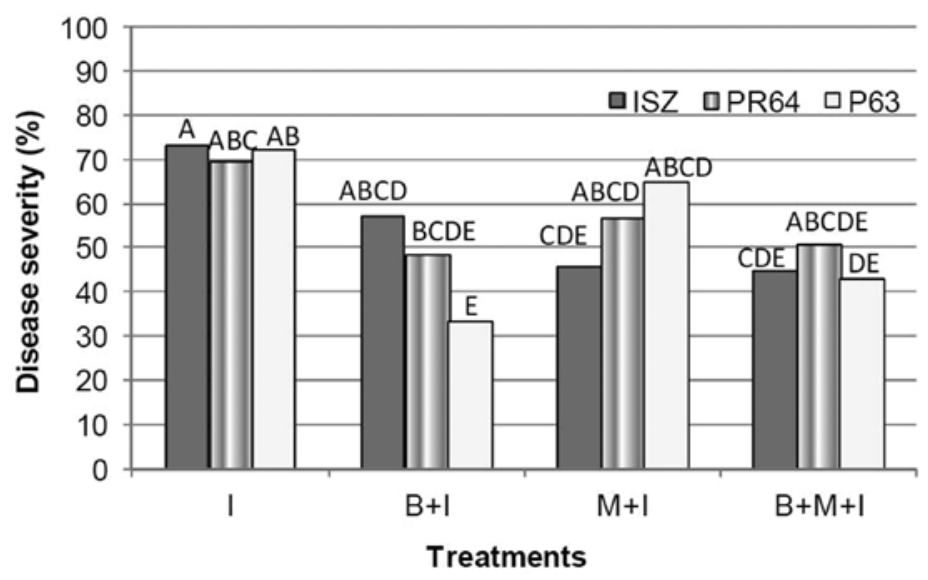

Fig. 1. Disease severity of BTH-treated and/or mycorrhiza-infected sunflowers show different levels of resistance to Sclerotinia sclerotiorum at 4 dpi. ISZ, cv. Iregi szürke csíkos; PR64, hybrid PR64H41; P63, hybrid P63LE13; I, inoculated, non-treated; B+I, BTH-treated and inoculated; M+I, mycorrhiza-mediated and inoculated; $\mathbf{B}+\mathbf{M}+\mathbf{I}, \mathrm{BTH}$-treated and mycorrhiza-mediated, inoculated. Columns represent mean values $(n=29-47)$. Different letters indicate significant differences based on Fisher's LSD test at $P<0.05$

plants (I) of all genotypes died by 7 days after inoculation. BTH treatment alone reduced disease severity, although it was significant only in the case of hybrid P63. Mycorrhiza alone decreased the disease severity in all genotypes, but the effect was only significant and strongest on ISZ, while the weakest effect was on P63. Furthermore, combined applications of inducers $(\mathrm{B}+\mathrm{M}+\mathrm{I})$ decreased the disease severity of these genotypes by approximately $40 \%$. There were no significant differences between the single $(\mathrm{B}+\mathrm{I}$ or $\mathrm{M}+\mathrm{I})$ and combined applications of inducers in ISZ plants. Combined treatment was as effective as single BTH treatment in P63 sunflowers. While disease development was also restricted in treated (either single or combined) PR64 sunflowers this decline could not be proven statistically significant (Fig. 1). Disease severity of treated plants remained as low at 7 dpi as at 4 dpi (data not shown) in the sunflower genotypes examined.

\section{Histological examination of induced resistance}

Host responses of ISZ sunflowers to infection by SS in hypocotil cross-sections are shown in Figure 2. Invaded cells of inoculated, non-treated plants turned brown and collapsed in a relatively short time after infection by S. sclerotiorum (Fig. 2A). This phenomenon was also observed in the non-treated hybrid (PR63) that is tolerant to Sclerotinia stalk rot. The pathogen completely degraded cells of inoculated, nontreated plants without any host response in each sunflower genotype (only cv. Iregi szürke csíkos is shown). In addition, hyphae of SS showed yellowish autofluores- 


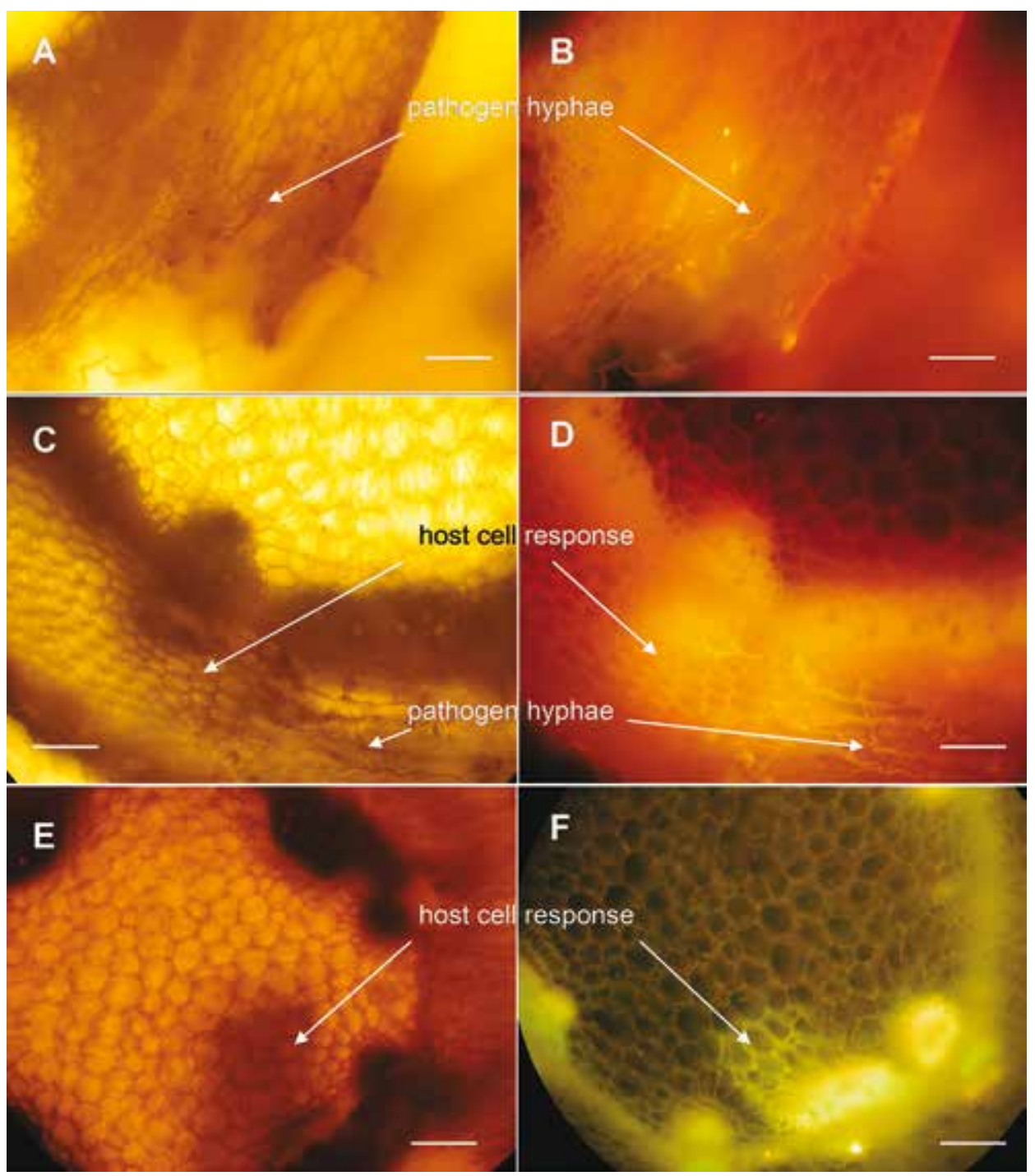

Fig. 2. Light micrographs of BTH- and/or mycorrhiza-mediated resistance responses in hypocotil crosssections of sunflower. Hyphae of Sclerotinia sclerotiorum invade cells of inoculated, non-treated susceptible plants (cv. Iregi szürke csíkos) without any host responses in normal (A) and in UV light (B) $(\lambda=485 \mathrm{~nm})$, at $2 \mathrm{dpi}$. Browning (C) and autofluorescence (D) of cortical parenchyma cells neighbouring invaded cells as a host response to pathogenic attack of BTH-treated and/or mycorrhiza-mediated, inoculated plants (PR64H41 hybrid), at 2 dpi. Browning (E) and autofluorescence (F) of pith parenchyma cells far from the place of initial infection indicating systemic effect of BTH-treated and/or mycorrhizamediated, inoculated sunflowers (P63LE13 hybrid), at 4 dpi. Scale bar $=100 \mu \mathrm{m}$ 
cence under UV excitation (Fig. 2B). In contrast, in BTH-treated and/or mycorrhizamediated, inoculated plants, browning of cortical parenchyma cells that neighboured invaded cells was a characteristic host response to pathogen attack at 2 dpi (only sections of PR64H41 hybrid are presented, Fig. 2C). Furthermore, the host cells adjacent to invaded ones showed intensive yellow-green autofluorescence under UV excitation (Fig. 2D). Four days after inoculation, browning and autofluorescence of pith parenchyma cells far from the initial infection site were detected in the majority of cross-sections of sunflowers P63 and ISZ, treated with BTH and/or mycorrhizal fungi, but not in PR64 (Fig. 2E-F). These plant parts (sections) were completely free from pathogenic hyphae. Interestingly, we could not find any autofluorescence reaction in the control (I) tolerant hybrid P63.

\section{Effect of BTH treatment on the mycorrhizal colonization}

Comparing control (mycorrhiza-mediated, non-treated, M) plants of three sunflower genotypes, there was a marked difference in the frequency $\mathrm{F}(\%)$ of mycorrhization (i.e. the ratio of infected and non-infected root fragments) among them (Table 1). F (\%) was the highest in ISZ control (M) sunflowers, followed by hybrid P63 plants after 21 days of growth. Interestingly, there was no colonization by AMF in the roots of mycorrhiza-mediated, non-treated PR64 (M) sunflowers. AMF colonization (F \%) of BTH-treated and mycorrhiza-mediated $(\mathrm{B}+\mathrm{M})$ plants were significantly higher than F\% of control (M) plants in P63 and PR64 hybrids. There was no statistical difference between the frequency of mycorrhization of control and BTH-treated ISZ sunflowers. Examining the intensity of mycorrhization and arbuscules abundance it can be stated that these parameters showed equally low values in all treatments and genotypes.

Table 1

Effect of BTH treatment on the mycorrhization of three sunflower genotypes after 21 days of growth

\begin{tabular}{|l|c|c|c|}
\hline \multirow{2}{*}{\multicolumn{1}{c|}{ Treatment }} & \multicolumn{3}{|c|}{ Mycorrhization } \\
\cline { 2 - 4 } & $\mathrm{F}(\%)$ & $\mathrm{M}(\%)$ & $\mathrm{A}(\%)$ \\
\hline ISZ M (control) & $15.6 \pm 2.5^{\mathrm{ab}}$ & $0.2 \pm 0.05^{\mathrm{c}}$ & $0^{\mathrm{c}}$ \\
\hline ISZ B + M (treated) & $11.1 \pm 3.5^{\mathrm{b}}$ & $0.7 \pm 0.2^{\mathrm{c}}$ & $0.2 \pm 0.1^{\mathrm{c}}$ \\
\hline PR64 M (control) & $0^{\mathrm{c}}$ & $0^{\mathrm{c}}$ & $0^{\mathrm{c}}$ \\
\hline PR64 B + M (treated) & $20.0 \pm 4.3^{\mathrm{a}}$ & $0.7 \pm 0.3^{\mathrm{c}}$ & $0^{\mathrm{c}}$ \\
\hline P63 M (control) & $4.4 \pm 2.5^{\mathrm{c}}$ & $0.1 \pm 0.06^{\mathrm{c}}$ & $0^{\mathrm{c}}$ \\
\hline P63 B + M (treated) & $18.3 \pm 2.1^{\mathrm{a}}$ & $2.2 \pm 0.5^{\mathrm{c}}$ & $0.9 \pm 0.7^{\mathrm{c}}$ \\
\hline
\end{tabular}

Data represent means of five replicates $(n=5)$. Values followed by means represent standard deviation. Different letters $\left({ }^{a},{ }^{b},{ }^{c}\right)$ indicate significant differences based on Fisher's LSD test at $\mathrm{P}<0.05$. F $(\%)-$ frequency of mycorrhization; M (\%) - intensity of mycorrhization; A (\%) - arbuscules abundance; ISZ - cv. Iregi szürke csíkos; PR64 - hybrid PR64H41; P63 - hybrid P63LE13; M - mycorrhiza-mediated, non-treated; B + M, $\mathrm{BTH}$-treated and mycorrhiza-mediated. 


\section{DISCUSSION}

According to our results, BTH and micorrhyza fungi restricted disease development of SS in treated plants. Effects of single applications of the tested inducers, however, seemed to be host-dependent in our study. It was also pointed out that the host genome seems to affect the protective effect provided by the AMF and a certain level of root mycorrhization is needed to provide bioprotection [27]. Studying mycorrhization of two sunflower genotypes slight differences were found in the reactions of plants, as well [6]. In addition, mycorrhization is affected by other factors such as plant nutrition, soil type, etc. [2]. In fact, sunflower genotypes responded distinctly to mycorrhizal colonization in our experiments. However, weak intensity of mycorrhization and arbuscules abundance can be explained by the relatively short time (4 weeks) of the experiment and this could result in unsatisfactory effects of AMF on disease development during the examination period.

In nature, plants are affected by various factors (pathogens with different lifecycles, symbionts such as mycorrhiza fungi, etc.) and it is clear now, that cross-talk exists between the different pathways they induce inside the plants, enabling the plant to adapt its response depending on the agent concerned. Examining cross-talk between pathways synergism (additive effect) and antagonism have also been found $[13,15]$. It was shown that BTH (as a salycilic acid analog) and an arbuscular mycorrhizal fungus, Glomus mosseae provided moderate or good protection against sunflower downy mildew (P. halstedii) [25]. In our study, the frequency of mycorrhization (F \%) of two sunflower hybrids (PR64 and P63) significantly increased upon BTH treatment. It seems, therefore, that BTH seed treatment has a positive effect on the formation of plant-mycorrhiza interactions in sunflower. Synergestic and cooperative effects among AMF and salycilic acid were also detected against Fusarium wilt in tomato [18]. In another study mycorrhization was not affected when BTH was applied as foliar spray, while it delayed AMF colonization upon soil drench against sunflower downy mildew [25]. In spite of this transient negative effect, combined applications resulted in moderate or good protection against this disease. Although root colonization by Glomus spp. was, to a smaller extent, affected negatively by exogenous SA or BTH treatments in these studies, the additive effect of inducers were significant against the plant diseases tested. In contrast, some of the researchers found that BTH had no significant effect on the frequency of colonization by G. mosseae but reduced the intensity of colonization and the proportion of arbuscules in soybean [10]. Later work, however, did not include interactions with pathogens, so induced resistance against diseases were not considered.

In our work, histological examination of host responses revealed that BTH and/or AMF treatment significantly decreased the development of pathogenic hyphae in ISZ and P63 plants. This was associated with intensive autofluorescence of cells either adjacent to, or far from the invaded tissues. Thus, both localized and systemic induction of resistance was observed in plants treated with BTH and/or AMF against S. sclerotiorum. Autofluorescence is usually connected with the accumulation of phenolic compounds which plays a significant role in the reaction of plants to patho- 
genic attack. In an earlier work of our research group, autofluorescence and the accumulation of reactive oxygen species (ROS) were also found to be associated with induced resistance in P. halstedii-infected and BTH-treated sunflower plants [3]. Changes in cell wall composition and accumulation of phenolic compound were also reported in sunflower flower parts infected by SS [21]. In addition, accumulation of fluorescent compounds was suggested to be involved in the induction of a localized and systemic resistance by an arbuscular mycorrhiza fungus against Phytophthora parasitica in tomato [7].

Since an integrated approach is crucial for the effective protection against $S$. sclerotiorum in sunflower, surveys on the efficacy of alternative and complementary methods such as induced resistance are significant. To our knowledge, this is the first report on the additive effect of $\mathrm{BTH}$ on mycorrhization and on the positive effect of BTH and AMF against SS in sunflower. Based on our findings and earlier positive results against downy mildew (P. halstedii) and white rot (S. sclerotiorum), the combined application of these inducers can be the source for further examinations. Followed by additional positive and supportive results they might be considered as biocontrol agents in future disease management of sunflower.

\section{ACKNOWLEDGEMENTS}

This work was kindly supported by the research grant from OTKA, No. 81209, and by Kutato Kari Kiválósági Támogatás - Research Centre of Excellence - 1476-4/2016/FEKUT. We are grateful to László Piukovics for providing Pioneer sunflower hybrids.

\section{REFERENCES}

1. Aysan, E., Demir, S. (2009) Using arbuscular mycorrhizal fungi and Rhizobium leguminosarum Biovar phaseoli against Sclerotinia sclerotiorum (Lib.) de Bary in the common bean (Phaseolus vulgaris L.). Plant Pathol. J. 8, 74-78.

2. Azcón-Aguilar, C., Barea, J. M. (1996) Arbuscular mycorrhizas and biological control of soil-borne plant pathogens - an overview of the mechanisms involved. Mycorrhiza 6, 457-464.

3. Bán, R., Virányi, F., Komjáti, H. (2004) Benzothiadiazole-induced resistance to Plasmopara halstedii (Farl.) Berl. et de Toni in sunflower. In: Spencer-Phillips, P. T. N (ed.) Advances in downy mildew research. Kluwer Academic Publishers, Dordrecht, pp. 265-273.

4. Barilli, E., Prats, E., Rubiales, D. (2010) Benzothiadiazole and BABA improve resistance to Uromyces pisi (Pers.) Wint. in Pisum sativum L. with an enhancement of enzymatic activities and total phenolic content. Eur. J. Plant Pathol. 128, 483-493.

5. Buzi, A., Chilosi, G., De Sillo, D., Magro, P. (2004) Induction of resistance in melon to Didymella bryoniae and Sclerotinia sclerotiorum by seed treatments with acibenzolar-S-methyl and methyl jasmonate but not with salicylic acid. J. Phytopath. 152, 34-42.

6. Chandrashekara, C. P., Patil, V. C., Sreenivasa, M. N. (1995) Response of two sunflower (Helianthus annuus L.) genotypes to VA-mycorrhizal inoculation and phosphorus levels. Biotropia 8, 53-59.

7. Cordier, C., Pozo, M. J., Barea, J. M., Gianinazzi, S., Gianinazzi-Pearson, V. (1998) Cell defense responses associated with localized and systemic resistance to Phytophthora parasitica induced in tomato by an arbuscular mycorrhizal fungus. Mol. Plant Microbe Int. 11, 1017-1028.

8. Dann, E., Diers, B., Byrum, J., Hammerschmidt, R. (1998) Effect of treating soybean with 2,6-dichloroisonicotinic acid (INA) and benzothiadiazole (BTH) on seed yields and the level of disease caused by Sclerotinia sclerotiorum in field and greenhouse studies. Eur. J. Plant Pathol. 104, 271-278. 
9. Ezzat, A. S., Ghoneem, K. M., Saber, W. I. A., Al-Askar, A. A. (2015) Control of wilt, stalk and tuber rots diseases using arbuscular mycorrhizal fungi, Trichoderma species and hydroquinone enhances yield quality and storability of Jerusalem artichoke (Helianthus tuberosus L.). Egypt. Journ. Biol. Pest Cont. 25, 11-22.

10. Faessel, L., Nassr, N., Lebeau, T., Walter, B. (2010) Chemically-induced resistance on soybean inhibits nodulation and mycorrhization. Plant Soil 329, 259-268.

11. Görlach, J., Volrath, S., Knauf-Beiter, G., Hengy, G., Beckhove, U., Kogel, K.-H., Oostendorp, M., Staub, T., Ward, E., Kessmann, H., Ryals, J. (1996) Benzothiadiazole, a novel class of inducers of systemic acquired resistance, activates gene expression and disease resistance in wheat. The Plant Cell 8, 629-643.

12. Harrach, B. D., Baltruschat, H., Barna, B., Fodor, J., Kogel, K.-H. (2013) The mutualistic fungus Piriformospora indica protects barley roots from a loss of antioxidant capacity caused by the necrotrophic pathogen Fusarium culmorum. Mol. Plant-Microbe Int. 26, 599-605.

13. Koornneef, A., Pieterse, C. M. J. (2008) Cross talk in defense signaling. Plant Physiol. 146, 839-844.

14. Körösi, K., Bán, R., Barna, B., Virányi, F. (2011) Biochemical and molecular changes in downy mildew-infected sunflower triggered by resistance inducers. J. Phytopath. 159, 471-478.

15. Mur, A. J., Kenton, P., Atzorn, R., Miersch, O., Wasternack, C. (2006) The outcomes of concentrationspecific interactions between salicylate and jasmonate signaling include synergy, antagonism, and oxidative stress leading to cell death. Plant Physiol. 140, 249-262.

16. MYCOCALC software package (2001) Retrieved from http://www2.dijon.inra.fr/mychintec/ Mycocalc-prg/download.html.

17. Oostendorp, M., Kunz, W., Dietrich, B., Staub, T. (2001) Induced disease resistance in plants by chemicals. Eur. J. Plant Pathol. 107, 19-28.

18. Özgönen, H., Bicici, M., Erkilic, A. (2001) The effect of salicyclic acid and endomycorrhizal fungus Glomus etunicatum on plant development of tomatoes and fusarium wilt caused by Fusarium oxysporum f. sp lycopersici. Turk. J. Agric. For. 25, 25-29.

19. Pozo, M. J., Azcon-Aguilar, C. (2007) Unraveling mycorrhiza-induced resistance. Cur. Op. in Plant Biol. 10, 393-398.

20. Prats, E., Rubiales, D., Jorrin, J. (2002) Acibenzolar-S-methyl-induced resistance to sunflower rust (Puccinia helianthi) is associated with an enhancement of coumarins on foliar surface. Physiol. Mol. Plant Pathol. 60, 155-162.

21. Rodríguez, M. A., Venedikian, N., Bazzalo, M. E., Godeas, A. (2004) Histopathology of Sclerotinia sclerotiorum attack on flower parts of Helianthus annuus heads in tolerant and susceptible varieties. Mycopathologia 157, 291-302.

22. Ryals, J., Uknes, S., Ward, E. (1994) Systemic acquired resistance. Plant Physiol. 104, 1109-1112.

23. Saharan, G. S., Mehta, N. (2008) Sclerotinia diseases of crop plants: biology, ecology and disease management. Springer Science+Business Media B.V.

24. Tosi, L., Luigetti, L., Zazzerini, A. (1999) Benzothiadiazole induces resistance to Plasmopara helianthi in sunflower plants. J. Phytopath. 147, 365-370.

25. Tosi, L., Zazzerini, A. (2000) Interactions between Plasmopara helianthi, Glomus mosseae and two plant activators in sunflower plants. Eur. J. Plant Pathol. 106, 735-744.

26. Trouvelot, A., Kough, J. L., Gianinazzi-Pearson, V. (1986) Mesure du taux de mycorhization VA d'un système radiculaire. Recherche de méthodes d'estimation ayant une signification fonctionnelle. In: Gianinazzi-Pearson, V., Gianinazzi, S. (eds) Physiological and Genetical Aspects of Mycorrhizae. Paris. INRA Press, pp. 217-221.

27. Vierheilig, H., Steinkellner, S., Khaosaad, T., Garcia-Garrido, J. M. (2008) The biocontrol effect of mycorrhization on soilborne fungal pathogens and the autoregulation of the AM symbiosis: One mechanism, two effects? In: Varma, A. (ed.) Mycorrhiza. Berlin Heidelberg, Springer-Verlag, pp. 307-320.

28. Walters, D. R., Ratsep, J., Havis, N. D. (2013) Controlling crop diseases using induced resistance: challenges for the future. J. Exp. Bot. 64, 1263-1280. 